\title{
European Fantasies: Modernism and Jewish Absence at the Venice Biennale of Art, 1948-1956
}

\author{
Frances Tanzer (D) \\ Strassler Centre for Holocaust and Genocide Studies, Clark University, 950 Main Street, Worcester, MA 01610, United States \\ ftanzer@clarku.edu
}

This article examines how states with a fascist past - Germany, Austria and Italy - used modernism in the visual arts to rebrand national and European culture at the Venice Biennale of Art after 1945. I argue that post-war exhibitions of modern art, including those at the Biennale, reveal a vast confrontation with Jewish absence after the Holocaust. Christian Democrats and proponents of European integration attempted to reimagine modernism without the Jewish minority that had shaped it in crucial ways. Meanwhile, living Jewish artists resisted their exclusion from the post-war interpretations of modernism, as well as absorbtion of modernism as part of national heritage. Their criticisms lay bare a seeming paradox at the heart of postwar Europe: a desire to claim the veneer of pre-Nazi cosmopolitanism without returning its enabling demographic and cultural diversity. This article points to the significance of philosemitism for establishing postwar national and continental identities.

\section{Introduction}

In 1952, the painter Léo Maillet (1902-90) asked the Secretary General of the Venice Biennale of Art, Rudolfo Pallucchini, to consider the construction of a pavilion for stateless artists at the important international art festival. 'The Biennale should not only be international', he exclaimed, 'it should be supranational. This would be the best way to mobilise the Biennale to contribute to the spread of peace.' The now unknown painter lamented that the Biennale's focus on the nation hindered its work as a site of cultural diplomacy and stood as a barrier to the participation of Jewish refugees in the exhibition. Maillet's challenge stemmed from his experiences as a victim of the 'degenerate' art policy and the Nazi persecution of Jews. A student of Max Beckmann, Maillet's paintings were stolen from Beckmann's atelier after the Nazis came to power in 1933. In 1935, Maillet fled Frankfurt, his city of birth, for Paris. Though he avoided deportation in 1942 by escaping to Switzerland, his work fell victim to the Nazis once again. In his Paris studio, the Gestapo destroyed 100 prints and 200 paintings. It was only in 1945 that he started a new life of work. As a stateless person, neither Switzerland (his country of residence) nor Germany (his country of birth) had ever extended Maillet an invitation to participate in their contribution to the Venice Biennale. If asked, however, he would have refused a German invitation both because of his persecution under the Third Reich and because of the continuation of antisemitism after $1945 .^{2}$

While Maillet found no national home for his work, his modernist pedigree and style resonated with the Biennale's focus on retrospective exhibitions of modernism from 1948 through 1956. During this period, the Christian Democratic and Europeanist planners and participants in the

\footnotetext{
1 Leo Maillet to Rodolfo Pallucchini, 15 Feb. 1952, Archivio Storico delle Arti Contemporanee (ASAC), Box 043, XXVI Biennale 1952. Atti II: 1950-3.

2 Ibid.

(c) The Author(s), 2021. Published by Cambridge University Press. This is an Open Access article, distributed under the terms of the Creative Commons Attribution licence (http://creativecommons.org/licenses/by/4.0/), which permits unrestricted re-use, distribution, and reproduction in any medium, provided the original work is properly cited.
} 
exhibition went to great lengths to ensure that modernism prevailed at the international festival. Exhibitions of modernism were a crucial component of cultural reconstruction after fascism and in the Cold War culture wars. The soft politics of modernist aesthetics assisted states with a fascist past - Germany, Austria and Italy - in their effort to reorient themselves away from fascism and toward Western Europe. The bureaucrats and curators who managed these projects presented modern art as part of a shared European cultural history that embodied the cosmopolitan, democratic and national values they hoped to restore after their destruction during the Nazi period. ${ }^{3}$

This was an agenda that found expression at other exhibitions in Europe. In Kassel, for example, documenta had a parallel cultural diplomatic function. We might view documenta 1 (1955) as an extension of the project of the Biennale curators and another node in the resurgence of modernism across the West. ${ }^{4}$ Still, the Biennale is a unique site for thinking about the evolution of modernism in relation to emerging European cultural identities due to its long history as a site of cultural diplomacy and the fact that it resumed in 1948.

Building from Maillet's example, this article proposes that we consider the post-war celebration of modernism within the framework of modern Jewish history and the aftermath of the Holocaust. ${ }^{5}$ In addition to modernism's importance for Europeans navigating the interlocking challenges of national reconstruction after fascism, European unification and Cold War posturing, I argue that the post-war exhibitions of modern art reveal a vast confrontation with Jewish absence after the Holocaust. ${ }^{6}$ To be sure, cultural reconstruction efforts proceeded in film, music, literature and popular entertainment, among other diverse arenas - one might identify Jewish absence as a component of reconstruction in each of these fields. ${ }^{7}$ Exhibitions of modern art, however, are distinctive in two regards. First, modernism became a key component of the Europeanist project after $1945 .^{8}$ To this end, exhibitions of

3 Nancy Jachec, Politics and Paintings at the Venice Biennale 1948-1964: Italy and the 'Idea of Europe' (Manchester: Manchester University Press, 2008); Jachec, 'Anti-Communism at Home, Europeanism Abroad: Italian Cultural Policy at the Venice Biennale, 1948-1958', Contemporary European History, 14, 2 (2005), 193-217.

4 Walter Grasskamp, 'Becoming Global: From Eurocentrism to North Atlantic Feedback - documenta as an "International Exhibition” (1955-1972)', OnCurating, 33 (2017), 25-33; Sabine Horn, 'documenta I (1955): Die Kunst als Botschafterin der Westintegration', in Johannes Paulmann, ed., Auswärtige Repräsentationen: Deutsche Kulturdiplomatie nach 1945 (Cologne: Böhlau Verlag, 2005), 45-62; Michael Wedekind, 'Abstraktion und Abendland: Die Erfindung der documenta als Antwort auf "unsere deutsche Lage”', in Ruth Heftrig and Nikola Doll, eds., Kunstgeschichte nach 1945: Kontinuität und Neubeginn in Deutschland (Cologne: Böhlau, 2006), 165-81.

5 Malachi Hacohen has recently pointed to the Jewishness of Cold War liberalism, including important figures in anti-communism, in: 'The Jewishness of Cold War Liberalism', in Abigail Green and Simon Levis Sullam, eds., Jews, Liberalism, Antisemitism: A Global History (London: Palgrave Macmillan, 2020), 387-410; Jacob and Essau: Jewish European History Between Nation and Empire (Oxford: Oxford University Press, 2019), 540-84.

6 On absence, see Julie Kalman and Daniella Doron, 'Absence in the Aftermath', Journal of Contemporary History, 52, 2 (2017), 197-210; Omer Bartov, 'Germans as Jews: Representations of Absence in Postwar Germany', in Omer Bartov, Germany's War and the Holocaust: Disputed Histories (Ithaca: Cornell University Press, 2003), 216-36.

7 On cultural reconstruction and Jewish absence, see Frances Tanzer, 'Performing the Austrian-Jewish (Negative) Symbiosis: Stella Kadmon's Viennese Stage from Red Vienna to the Second Republic', The Leo Baeck Institute Year Book, 63, 1 (2018), 179-97. There is a vast literature that argues that cultural reconstruction in various fields and national contexts assisted in establishing images of democratic and European states in the capitalist West. For example: Heide Fehrenbach, Cinema in Democratizing Germany: Reconstructing National Identity After Hitler (Chapel Hill: University of North Carolina Press, 1995); Dean Vuletic, Postwar Europe and the Eurovision Song Contest (London: Bloomsbury, 2018).

8 See Greg Barnhisel, Cold War Modernists: Art, Literature, and American Cultural Diplomacy (New York: Columbia University Press, 2015); Stephanie Barron, ed., Art of Two Germanys: Cold War Culture (New York: Abrams, 2009); Greg Castillo, Cold War on the Home Front (Minneapolis: University of Minnesota Press, 2010); Sabine Hake and Philip Broadbent, eds, Berlin: Divided City, 1945-1989 (New York: Berghahn Books, 2010); Wolfgang Schivelbusch, In a Cold Crater (Berkeley: University of California Press, 1999); James M. Robertson, 'Navigating the Postwar Liberal Order: Autonomy, Creativity and Modernism in Socialist Yugoslavia, 1949-1953', Modern Intellectual History 17, 2 (2020), 385-412; Maike Steinkamp, Das unerwünschte Erbe: Die Rezeption 'entarteter' Kunst in Kunstkritik, Ausstellungen und Museen der Sowjetischen Besatzungszone und der frühen DDR (Berlin: Akademie Velag, 2008); on the specific case of the Biennale, see Jachec, Politics and Paintings and 'Anticommunism at Home, Europeanism 
modern art reveal cultural reconstruction after fascism as a transnational and international process. ${ }^{9}$ Second, a robust literature reveals Jews as a constitutive part of the societies and cultures that produced modern art and urban culture. ${ }^{10}$ At the same time that individual Jews, such as Maillet, produced and supported modern art, antisemites and philosemites also coded modernist and urban culture 'Jewish' regardless of the presence or absence of Jews. ${ }^{11}$ In other words, Jewish coding and stereotypes played a key role in the interpretation of modern art before and during the fascist period. Post-war exhibitions, then, lay bare a foundational and usually unspoken question of post-war reconstruction. How should a cultural universe previously marked by a real and imagined Jewish presence be repurposed in the face of Jewish absence? To confront this challenge, the Italian, German and Austrian Christian Democrats who presided over the post-war Biennale reimagined modernism without the Jewish minority that had shaped it in a variety of crucial ways. At the same time, the exhibition and interpretation of modern art at the Biennale and elsewhere exposes the significance - and transformation - of a discourse of Jewish difference for establishing post-fascist national and continental identities.

Maillet makes clear that the post-war revision of modernism as a key component of national heritage did not go uncontested. As this article details, modernist artists, critics, their families and especially Jewish refugees resisted this appropriation of their art and the world from which it emerged. Their criticisms of the post-war reconstruction efforts expose a paradox at the heart of post-war national identity: a desire to claim the veneer of pre-Nazi cosmopolitanism without returning its enabling demographic and cultural diversity. The critics of the first post-war decades were largely unable to disturb the arrogation of their work by artistic and state elites intent on rehabilitating their nations after the fascist catastrophe.

The history of the Biennale from 1948 through 1956 provides a crucial context for analysing transformations in the meaning ascribed to modern art. Founded in 1895 as a space primarily for Italian painting, the Biennale blossomed by the early twentieth century into a premier international fine arts exhibition at a moment when international exhibitions and festivals - like the World's Fair - proliferated and showcased imperial power. ${ }^{12}$ The construction of the permanent national pavilions in the Giardini, the public gardens in which the exhibition is held, in the first decade of the twentieth century consolidated the exhibition's role as a space for national aesthetic performance and revision. The architect of the national pavilions, General Secretary Antonio Fradeletto, understood them as a way to guarantee 'the most favourable international solidarity'. ${ }^{13}$ As Angela Vettese observes, the national pavilions 'oblige us to keep a constant eye on geopolitical history as reflected in the arts'. ${ }^{14}$ The Biennale provides an imaginative landscape, between reality and fantasy, where participants reimagine cultural identities and boundaries. ${ }^{15}$ In this way, the Biennale affords us an opportunity to examine the aspirations and assumptions of a post-war order as it came into being.

Abroad'; Ursula Zeller and Institut für Auslanderbeziehungen, eds., Die deutschen Beiträge zur Biennale Venedig, 18952007 (Cologne: DuMont, 2007).

9 Gerd-Rainer Horn and Padriac Kenney, 'Introduction: Approaches to the Transnational', in Gerd-Rainer Horn and Padraic Kenney, eds., Transnational Moments of Change: Europe 1945, 1968, 1989 (Lanham: Rowman \& Littlefield, 2004).

10 Among others: Steven Beller, Vienna and the Jews (Cambridge: Cambridge University Press, 1989); Gemma Blackshaw, ed., Facing the Modern: The Portrait in Vienna 1900 (London: National Gallery Company, 2013); Mary Gluck, The Invisible Jewish Budapest (Madison: University of Wisconsin Press, 2016); Klaus Hödl, Kulturelle Grenzräume im jüdischen Kontext (Innsbruck: Studienverlag, 2008); Klaus Hödl, Wiener Juden-jüdische Wiener: Identität, Gedächtnis und Performanz im 19. Jahrhundert (Innsbruck: Studien Verlag, 2006); Marlene Otte, Jewish Identities in German Popular Entertainment, 1890-1933 (Cambridge: Cambridge University Press, 2006); Shachar M. Pinsker, A Rich Brew: How Cafés Created Modern Jewish Culture (New York: New York University Press, 2018); Lisa Silverman, Becoming Austrians (Oxford: Oxford University Press, 2012); Scott Spector, Prague Territories (Berkeley: University of California Press, 2000); Sarah Wobick-Segev, Homes Away From Home: Jewish Belonging in Twentieth-Century Paris, Berlin, and St. Petersburg (Stanford: Stanford University Press, 2018).

11 Gluck, The Invisible Jewish Budapest; Silverman, Becoming Austrians.

12 Caroline Jones, 'Biennial Culture: A Longer History', in Clarissa Ricci, ed., Starting from Venice: Studies on the Biennale (Venice: Università Luav di Venezia, 2010), 28-50.

13 Quoted in Vittoria Martini, 'The Evolution of an Exhibition Model: Venice Biennale as an Entity in Time', in Vittoria and Frederica Martini, eds., Just Another Exhibition. Histories and Politics of Biennales (Milan: Postemdiabooks, 2011), 120.

14 Angela Vettese, 'Preface', in Clarissa Ricci, ed., Starting from Venice, 8.

15 See: Edward W. Soja, Thirdspace: Journeys to Los Angeles and Other Real-and-Imagined Places (Oxford: Blackwell, 1996). 
At the Biennale, Europeans traded in fantasies that contradicted the reality of destroyed cities after 1945. Their fantasies betrayed realities of a different sort. The modernist agenda promoted an international order founded on the primacy of the nation-state and the corresponding simplification of Europe's cultural history. The process of cultural reconstruction - or better, translation - that this article examines had important and long-term consequences for Jewish refugee artists, as well as for discussions about the right of Jews and other minorities to participate in European culture after 1945. Europeans dragged antisemitic and philosemitic frameworks into the post-war world but transformed them to suit exigencies of the new epoch. The celebration of modernism at the Biennale points to a changed order, which valued the cultural materials that were previously coded 'Jewish' as historical evidence of the redemptive, European and democratic society that the post-war Europeans hoped to build - this time without the Jews. It is that seemingly paradoxical mixture of a superficial cosmopolitanism and a fundamentally exclusive national identity that Jewish and Jewish-coded cultural figures laid bare through their criticisms in the 1950s. Today, the stakes of participating in the Biennale remain high. 'If you don't exhibit, you don't exist', Salah Hassan and Olu Oguibe exclaimed as they reflected on the historic exclusion and marginalisation of African contributions. ${ }^{16}$ In other words, the tensions of exclusion and symbolic representation that this article analyses continue to shape the exhibitions as they did in the first post-war decades.

\section{Modernism and Jewish Absence}

Before the 1940s, modernist art had represented a challenge to the status quo. While modernist visual artists comprised a range of movements, styles, objectives and political commitments, they shared a tendency to use strategies of abstraction and fragmentation to shock viewers and criticise bourgeois conventions. A mutual disdain between the artists and bourgeois society distinguished them as outside of the mainstream before the 1940s. ${ }^{17}$ To be sure, the self-proclaimed antagonism between the modernists and bourgeois society was not steadfast. ${ }^{18}$ While both modernists and avant-gardists were opposed to bourgeois society in their self-perception, they were often intimately entangled in practice. Their biographies, urban contexts, networks of friends and financial realities linked them in powerful ways to bourgeois society. By the early twentieth century, for example, many who would become key figures in the modernist canon had gained the support of important, sometimes Jewish, collectors. ${ }^{19}$ Still, acceptance amongst a narrow group of patrons was a far cry from the official and popular support that would emerge a few decades later.

The modernist agenda at the Biennale fit into a broader celebration of modern art after 1945. Dealers and gallerists referred to the period from 1945 through the mid-1950s as a 'modernism boom'. ${ }^{20}$ On the whole, art dealers benefited from modernism's newfound popularity and the correspondingly high prices the works fetched at auction. The institutionalisation of modernism and its popular embrace, however, signalled a radical shift in its interpretation, reception and sometimes the personnel involved in promoting the works. Even an elite figure as enmeshed in the world of modern art trade as the Munich dealer Günther Franke opined the newfound centrality of politicians and bureaucrats in shaping the meaning and market for modernist works after $1945 .{ }^{21}$ Formerly of interest

16 Quoted in: Christine Eyene, 'Africa at the 55th Venice Biennale: Of Achievements and Illusions', African Arts, 47, 1 (2014), 1.

17 On the distinction between avant-gardists and modernists and its obfuscation in the postwar period, see Barnhisel, Cold War Modernists, 33; Peter Bürger, Theory of the Avant-Garde (Minneapolis: University of Minnesota, 1984).

18 Many scholars have shown that the relationship between modernists and avant-garde artists and bourgeois society was much more complex than total disavowal. For example: Gemma Blackshaw, Facing the Modern; Mary Gluck, Popular Bohemia (Cambridge, MA: Harvard University Press, 2008); Andreas Huyssen, After the Great Divide (Bloomington: Indiana University Press, 1996); Elana Shapira, Style and Seduction (Waltham: Brandeis University Press, 2016).

19 Shapira, Style and Seduction; Blackshaw, Facing the Modern.

20 Günther Franke to Curt Valentin, July 1954, MoMA Museum Archives, Curt Valentin Papers, VII.A.2, E-H.

21 Ibid. 
to a narrow and elite group of collectors, modern art caught the eye of politicians and officials across the West as a useful cultural heritage for the war against totalitarianism.

Modernist and avant-garde works took on an unprecedented significance in national aesthetic policy and cultural diplomacy in stark contrast to their prior exclusion. Broad acceptance coincided with - and relied on - the homogenisation of a diverse spectrum of modernist and avant-garde artists. Greg Barnhisel has attributed modernism's middlebrow acceptance in the United States to the permeation of the idea of aesthetic autonomy. Americans learned to value artworks as 'autonomous aesthetic objects' that did not derive their significance from their historical context or from the biographies of the artists. Emptied of its radical and challenging political content, modernism became a shorthand for a vague notion of individual freedom and creativity that could only be found in democratic regimes. The apolitical interpretation of modernism provided a counterpoint to the Eastern Bloc, where the tight associations between art and politics supposedly suppressed creative expression. ${ }^{22}$

Like Americans, post-war Europeans embraced aspects of aesthetic autonomy in order to reinvent modernism as an appropriate cultural heritage for the post-war order. At the same time that Europeans understood modernists in the general terms set by the Cold War cultural battles, they used modernist art to rehabilitate and redeem national identities in the aftermath of fascism. Proponents of modernism in Europe after 1945 presented modernist artists as victims of totalitarian regimes and evidence of the enduring democratic potential of European states. At the Biennale and elsewhere, curators reimagined the society from which modern art had emerged. Exhibitions obfuscated the Jewish and Nazi past of European modernism in the service of post-war national reconstruction and European unification.

A shifting interpretation of the relationship between modernism, Jewishness and national identity undergirded the transformation of modern art in the post-war period. Before the 1930s, modern art was defined in part by a Jewish presence. Jewish artists, critics, curators, dealers and collectors supported the development of modern art across Central Europe. In turn, modern art sometimes gave them tools to reimagine Jewish identities in a post-emancipation epoch where many sought alternatives to tradition in a changing world that did not always welcome them. As Gemma Blackshaw has argued, for example, the art dealers Otto Kallir, August and Erich Lederer and August Reininghaus understood the Viennese modernist painter Egon Schiele's self-portrait nudes as a reflection of their own emasculation and exclusion from Viennese society. Still, such paintings allowed these men to transcend exclusion by providing them with membership to an elite and avant-garde group of collectors. ${ }^{23}$ Modernist painting, collecting, exhibition and criticism gave those Jews who participated a space to think through some of the most important issues of post-emancipation Jewish life: antisemitism, Jewish and non-Jewish relations and the establishment of secular Jewish cultures. ${ }^{24}$

At the same time that Jews co-created and supported modernist art and urban culture, they also became spectral figures in a discourse that fantasised - and often fulminated - about their dominance regardless of Jewish presence or absence. A pervasive Central European discourse coded modern and urban spaces 'Jewish' in order to pass judgement on them. For example, though the modernist painter Gustav Klimt was not Jewish, he was often accused by his detractors of representing a so-called 'Jewish taste. ${ }^{25}$ In Italy a version of this discourse prevailed among Catholic intellectuals, who used antisemitism as a tool in their campaign against modernism. ${ }^{26}$

\footnotetext{
22 Barnhisel, Cold War Modernists, 39-40.

23 Blackshaw, Facing the Modern, 120.

24 This is part of what Wobick-Segev has deemed a 'spatial revolution'. Wobick-Segev, Homes Away from Home, 6.

25 Shapira, Style and Seduction, 7.

26 Nina Valbousquet shows how integralist Catholics linked modern culture, especially film, to antisemitic stereotypes: 'Catholic Anti-Modernism and the Modernity of Fascism: Integralist Catholicism, Nationalism, and Antisemitism in Fede e Ragione (1919-1929)', Incontri, 32 (2017), 88-9; on Catholic antisemitism/anti-modernism, see J.D. Lebovitch Dahl, 'The Role of the Roman Catholic Church in the Formation of Modern Anti-Semitism: La Civiltà Cattolica, 1850-79', Modern Judaism, 23 (2003), 180-97; on the anti-bourgeois campaign: Marie-Anne Matard-Bonucci, L'Italie fasciste et la persécution des juifs (Paris: Perrin, 2007).
} 
Jewish coding was not only a matter of obscure cultural debate. A discourse of Jewish difference rested at the heart of discussions of European culture and nationalism. This coding intersected with the establishment of art historical practice as an important vehicle for nationalism. As Margaret Olin has argued, Jews have long battled allegations of being a 'nation without art'. Antisemitic stereotypes describe Jews as exotic, superficial, capable only of imitation, or unable to produce art altogether. Such stereotypes suggested that Jews, allegedly burdened by cosmopolitan associations, have been unable to sensually embody a work of art or comprehend the national soul well enough to produce any art suitable for a national canon. German-Jewish painter Max Liebermann, for instance, faced frequent accusations from antisemites and nationalists that his work was not authentically German and could just as easily have been French or Dutch. ${ }^{27}$

Antisemites were the most vocal and consistent proponents of this discourse. ${ }^{28}$ Yet, modernists and their supporters also reflected on the association between Jews and modern culture. Wilhelm Hausenstein exposed and denounced the antisemitism that undergirded discussions of Max Liebermann in the press. ${ }^{29}$ Others inverted antisemitic categories. Klimt, for example, used the perceived association of his works with Jewishness to emphasise his outsider status as a bohemian and an artist. ${ }^{30}$ Meanwhile, Hugo Bettauer's enormously popular satirical novella, The City without Jews (Die Stadt Ohne Juden), imagines the cultural consequences of the realisation of the antisemitic dream of removing Jews from the city. In Bettauer's hands, the removal of the Jewish minority transforms the once cosmopolitan city into a provincial backwater. ${ }^{31}$ Though these philosemitic interpretations challenged antisemites and poked fun at their cultural backwardness, they did little to promote a culture of tolerance. Philosemitism, too, relied on a language of Jewish difference in order to establish meaning. Antisemitic anti-modernists and philosemitic pro-modernists disagreed fiercely about how to assess what Scott Spector calls 'Jewish modernism', but they shared an assumption of a direct correlation between Jewish presence and urban modernity. ${ }^{32}$

'Jewish modernism' provided an interpretive framework for thinking about the boundaries of national identity and culture. In the nineteenth and early twentieth century, the discourse of Jewish difference, as Lisa Silverman makes clear, presented the modern city as a Jewish - and therefore foreign - space, defined in opposition to the authentic nation. ${ }^{33}$ In other words, this discourse established and sometimes helped to redraw the boundaries of the nation. From this perspective, the formalism and aesthetic autonomy of post-war Jewish art critics Clement Greenberg and Harold Rosenberg might be read not only as a way to strip modernism of politics, but also as a defence against the historic associations between modernism and Jewishness. ${ }^{34}$

Of course, the connections between Jews and modernism were never entirely straightforward. National Socialism, in particular, both simplified and complicated such associations. The Degenerate Art Exhibition (1937) took the discourse of 'Jewish modernism' to its antisemitic extreme. Nazi leaders coded modernist works as 'degenerate', 'Jewish', 'Bolshevik' and as evidence of mental illness. In turn, they confiscated modernist works from national collections (and often sold them abroad). ${ }^{35}$ With only eight Jewish artists featured, however, the exhibition concerned itself primarily with works that

\footnotetext{
27 Margaret Olin, The Nation without Art: Examining Modern Discourses on Jewish Art (Lincoln: University of Nebraska Press, 2001), 25.

28 At times, such associations were absent from the discussions of proponents of modernism altogether: Kurt Winkler, Museum und Avantgarde: Ludwig Justis Zeitschrift Museum der Gegenwart und die Musealisierung des Expressionismus (Wiesbaden:VS Verlag für Sozialwissenschaften, 2002).

29 Olin, The Nation without Jews, 26.

30 Shapira, Style and Seduction, 7.

31 Hugo Bettauer, Die Stadt Ohne Juden: Ein Roman von übermorgen (Vienna: Gloriette, 1922).

32 Scott Spector, 'Modernism without Jews: A Counter-Historical Argument', Modernism/modernity, 13, 4 (2006), 615-33; Spector, Modernism without Jews? (Bloomington: Indiana University Press, 2017).

33 Lisa Silverman, Becoming Austrians.

34 Olin, The Nation without Jews, 27.

35 See Stephanie Barron and Lisa Vihos, eds., Degenerate Art (Los Angeles: Los Angeles County Museum of Art, 1991). Jonathan Petropoulos, The Faustian Bargain (Oxford: Oxford University Press, 2000); Petropoulos, Art as Politics in
} 
had been judaised. ${ }^{36}$ The Degenerate Art Exhibition represented the symbolic exclusion of modern art and with it, all of the groups that National Socialists imagined modern art to represent - from German culture and cultural history.

The hardening of the aesthetic policy in 1937 draws our attention to the ambivalence that shaped Nazi aesthetic policy prior to the Degenerate Art Exhibition. Several members of the National Socialist elite promoted modernism as a representative aesthetic for the Reich. Joseph Goebbels, for instance, admired the works of the modernists Emil Nolde and Ernst Barlach before 1937. He championed Expressionism as the representative Nazi aesthetic in opposition to anti-modernists like Alfred Rosenberg. The argument for Expressionism's inclusion in the Reich proposed that such works were manifestations of a German soul and the best way to relate the spiritual experience of war and violence. ${ }^{37}$ Expressionists like Nolde presented their artworks as a pure, völkisch cultural form, defined against the so-called 'Jewish' and foreign influences of the modern city. Nazi aesthetic policy eventually hardened against Nolde and he was included in the Degenerate Art Exhibition. His inclusion, however, did not signal opposition to the regime. ${ }^{38}$ Making modernist art the symbol of the liberal and democratic West after 1945 required occluding the fact that modernism lacked a clear political orientation. Many modernist artists had been connected to socialist, communist and fascist parties. When the 1952 West German contribution to the Venice Biennale featured Nolde, it did so within the framework of the post-war revision of modernism that took his inclusion in the Degenerate Art Exhibition as a sign of his victimisation, as well as an opportunity to forget his antisemitism and support of National Socialism. ${ }^{39}$

Fascist aesthetic policies also varied regionally. In Italy, Mussolini reigned in artistic expression through an extensive patronage system, but allowed for variation in artistic approaches. ${ }^{40}$ Moreover, there were strong associations between Italian Futurism and fascism. ${ }^{41}$ In Vienna, Nazi leadership presented modernist painters like Egon Schiele and Gustav Klimt as representatives of a unique Viennese contribution to the Nazi vision of Europe. ${ }^{42}$ Exhibitions and interpretations of Schiele and Klimt's paintings reinvented the artists as an appropriate cultural heritage for the Reich by removing all references to their Jewish supporters, colleagues and subjects. ${ }^{43}$ The intellectual work required to bring modernism into a mainstream national narrative, then, was already underway during the fascist period.

Post-war champions of modern art ignored the chequered history of modernism under totalitarianism and presented modernism as a radical aesthetic and ideological break from fascism and

the Third Reich (Chapel Hill: University of North Carolina Press, 1996); Frederic Spotts, Hitler and the Power of Aesthetics (London: Hutchinson, 2002).

36 Neil Levi, Modernist Form and the Myth of Jewification (New York: Fordham University Press, 2014 ), 55.

37 Gregory Maertz, Nostalgia for the Future: Modernism and Heterogeneity in the Visual Arts of Nazi Germany (Stuttgart: ibidem-Verlag, 2019); Maertz, 'Modernist Art in the Service of Nazi Culture: Baldur von Schirach and the Junge Kunst im Deutschen Reich Exhbition', Patterns of Prejudice, 50, 4/5 (2016), 337-58.

38 Bernhard Fulda and Aya Soika, eds., Emil Nolde. Eine deutsche Legende - Der Künstler im Nationalsozialismus (Munich: Prestel, 2019); Peter Paret, German Encounters with Modernism (Cambridge: Cambridge University Press, 2001), 202-29.

39 Eberhard Hanfstaengl, 'Germania', in Biennale di Venezia, ed., Catalogo: XXVI Esposizione biennale internazionle d'arte (Venice: C. Ferrari, 1952), 284-98.

40 Ruth Ben-Ghiat, Fascist Modernities: Italy, 1922-1945 (Berkeley: University of California Press, 2001); Marla Stone, Patron State: Culture and Politics in Fascist Italy (Princeton: Princeton University Press, 1998).

41 Philip V. Cannistraro, La fabbrica del consenso: fascismo e mass media (Rome: Laterza, 1975); Giovanni Lista, Futurism (New York: Universe Books, 1986); Ernest Ialongo, Filippo Tommaso Marinetti: The Artist and His Politics (Madison, WI: Fairleigh Dickinson University Press, 2015).

42 The newspapers of post-Anschluss Vienna are filled with reviews of exhibitions featuring Schiele and Klimt. For example: N.a., Kleine Volks-Zeitung, 1 Oct. 1943, 6; Dr. Lee Springschitz, 'Triumph des Wiener Kunsthandwerkes', Neues Wiener Tagblatt, 1 Oct. 1943, 3 .

43 Maertz, 'Modernist Art in the Service of Nazi Culture'; Laura Morowitz, 'Heil the Hero Klimt!': Nazi Aesthetics in Vienna and the 1943 Gustav Klimt Retrospective', Oxford Art Journal, 39, 1 (2016), 117-22. On the Austrian version of the Degenerate Art Exhibition: Ernst Ploil, 'The "Entartete Kunst” Exhibitions in Austria', in Olaf Peters, ed., Degenerate Art: The Attack of Modern Art in Nazi Germany, 1937 (New York: Neue Galerie, 2014), 126-35. 
communism. Post-war figures in the West imagined modernism as a redemptive return of the European cultural universe destroyed first by the Second World War and then by Cold War division. The image of aesthetic discontinuity occluded the contradictory ways in which the ambiguities of fascist aesthetic policies and a confrontation with Jewish absence shaped the post-war revision. The acceptance of modernism by particular individuals and regions during the fascist period helped to establish the foundation for modernism's inclusion into an official cultural narrative after 1945. Meanwhile, the power of modernism to recast formerly fascist countries as European and democratic in the post-war period came at least in part from its associations with cosmopolitanism and urban identity, both of which were key components in the discourse of Jewish modernism.

What remained of this discourse after 1945, then, were some of the stereotypes that had linked Jews to modern culture. Those stereotypes, in their antisemitic and philosemitic variants, proceeded curiously without Jews. To be sure, post-war Europeans understandably did not wish to draw the same troubling and tight connection between Jews and modern culture that had been central to the aesthetic policy of Nazi Germany. As Lisa Silverman has argued, this impulse helped to produce an 'antisemitism without the Jews'. Antisemitic stereotypes persisted, but proponents seldom attributed those stereotypes to 'Jews' explicitly. ${ }^{44}$

The philosemitic component of 'Jewish modernism' also persisted and transformed after 1945. Frank Stern has argued that in West Germany philosemitism emerged in the immediate post-war period as a way for Germans to reinvent themselves as democrats in the eyes of Allies but did not preclude the continuation of antisemitism. ${ }^{45}$ This article considers those observations in a broader European framework. Much like 'antisemitism without Jews', we might speak of philosemitism without Jews as a crucial factor for Europeanists wishing to establish a European cultural identity after 1945. Yet, the continuation of philosemitic stereotypes, as this example of the Biennale makes clear, hardly paved the way for the inclusion of Jewish artists and it did not contradict antisemitism. Rather, it reflected a world where Jewish difference remained one of the primary modes for thinking about national and continental identities. ${ }^{46}$ At the same time, the absence of explicit discussion of Jews represents a fundamental shift in the discourse. This transformation is apparent in the post-war effort to revive the Biennale.

\section{The Post-war Venice Biennale and Christian Democracy}

The Biennale Secretary General Rudolfo Pallucchini and President Giovanni Ponti, both Christian Democrats, sought to repair the festival's tarnished reputation after 1945. Mussolini and Hitler had recognised the international significance of the Biennale and used it to promote a fantasy of fascist Europe. Adolf Ziegler, Nazi ideologue and president of the Reich Chamber for Visual Arts, filled the German Pavilion with Arno Breker's neoclassical 'Aryan' forms, German landscapes and images of war. ${ }^{47}$ The exhibitions depicted the new racial order that the National Socialists hoped to create and suggested the means for creating it - a world war to acquire German land for 'pure' German bodies. Meanwhile, Italy directed the broader message of the festival towards militarism. ${ }^{48}$ Ponti and

$\overline{44}$ Lisa Silverman, 'Absent Jews and Invisible Antisemitism in Postwar Austria: Der Prozeß (1948) and The Third Man (1949)', Journal of Contemporary History, 52, 2 (2017), 211-28.

45 Frank Stern, The Whitewashing of the Yellow Badge: Antisemitism and Philosemitism in Postwar Germany (Oxford: Pergamon, 1991).

46 Austrians, in fact, continued to use a - now transformed - discourse of Jewish difference and a hierarchical relationship between Jews and non-Jews to articulate a post-Nazi national identity. See Robert Knight, 'National Construction Work and Hierarchies of Empathy in Postwar Austria', Journal of Contemporary History 49, 3 (2014), 491-513; Silverman, 'Absent Jews and Invisible Antisemitism in Postwar Vienna'; Tara Zahra, 'Prisoners of the Postwar: Expellees, Displaced Persons, and Jews in Austria after World War II', Austrian History Yearbook, 41 (2010), 191.

47 Adolf Ziegler, 'Padiglione della Germania', in Biennale di Venezia, ed., Catalogo: XXI Esposizione biennale internazionle d'arte (Venice: C. Ferrari, 1938), 254-67; Ziegler, 'Padiglione della Germania', in Biennale di Venezia, ed., Catalogo: XXII Esposizione biennale internazionle d'arte (Venice: C. Ferrari, 1940), 249-57; Ziegler, 'Padiglione della Germania', in Biennale di Venezia, ed., Catalogo: XXI Esposizione biennale internazionle d'arte (Venice: C. Ferrari, 1942), $263-69$.

48 Ibid. 
Pallucchini hoped to redeem the Nazi vision of Europe presented at the Giardini just a few years earlier with an image of cooperative, integrated European identities.

The Biennale provided a space for Christian Democrats to thicken their transnational networks and promote a Europeanist culture founded on catholic cosmopolitanism and national salvation. ${ }^{49}$ Exhibitions of modernism helped them to achieve both goals. Ponti and Pallucchini's support of modernism emerged from their staunch anti-communism. They understood the modernist exhibitions as a way to assert Italy's importance in the Cold War culture wars, while also jostling for power with Italy's communist party (the PCI). With the largest communist party outside of the Eastern Bloc countries, any increase in the prominence of the PCI could threaten their project of cultural diplomacy. ${ }^{50}$ For Pallucchini, emphasising a shared history of modernism helped to re-establish Italy's connection to Western Europe. His modernist agenda also had a pedagogical function. It allowed young artists to 'get to know and compare' different international art movements. ${ }^{51}$ The avant-garde, he concluded, reflected the 'new climate of liberty, hard won of the European spirit' which had defended the 'liberty of Western European culture' against fascism and communism. ${ }^{52}$ The Biennale, then, emphasised the importance that Christian Democrats placed on cultural work in their efforts to consolidate power and push for an integrated Europe.

The productive exchange of modernist artworks served a crucial diplomatic function after 1945 . Italy's project did not initially include German participation. At the first post-war Biennale in 1948, Pallucchini decided to use the German pavilion to house an exhibition of French Impressionism the focal point of the exhibition that year. ${ }^{53}$ However, the willingness of the Munich-based curator Eberhard Hanfstaengl to collaborate on the modernist agenda of the Biennale helped him to earn space for a German exhibition in the 1948 festival.

A member of the Christian Social Union, the Christian Democratic and conservative party of Bavaria, Hanfstaengl was active in establishing the cultural policy of West Germany. The 1948 exhibition meant a return of Hanfstaengl to the Venice Biennale after a twelve-year hiatus. The National Socialist leadership had removed Eberhard as curator at the Biennale and director of Berlin's Nationalgalerie in 1937 due to his opposition to the 'degenerate' art policy. ${ }^{54}$ Since he was not implicated in Nazi crimes, the Western occupation authorities duly appointed him as the director to both the Bayerischen Staatsgemaeldesammlungen and the Central Collecting Point for Looted Art. ${ }^{55}$ In 1948, Hanfstaengl's cooperation with the Italian planners and his ability to provide important French Impressionist paintings for the central exhibition demonstrated a sufficiently clean break with the past for the Italian planners to propose a small exhibition of Munich-based artists. ${ }^{56}$ In the catalogue, he framed the 1948 exhibition as an attempt to heal cultural relations with Western Europe and to end the cultural isolation imposed by the National Socialists. ${ }^{57}$

At the Biennale, the post-war architects of the revision of modernism at once celebrated the philosemitic association of cosmopolitan with modernism and attempted to attach modernists to non-Jewish coded elements, such as non-capital cities, the countryside and non-Jewish artists. Hanfstaengl's curatorial project in the 1950s reflected this post-war revision of modernism. For Hanfstaengl, the potential to create a German exhibition meant 'the renewal of a lively connection between our countries [Italy and Germany] and especially between our cities [Venice and

\footnotetext{
49 See Mark Edward Ruff, The Battle for the Catholic Past in Germany, 1945-80 (Cambridge: Cambridge University Press, 2017).

50 Jachec, Politics and Paintings; Jachec, 'Anti-Communism at Home, Europeanism Abroad'.

51 Rodolfo Pallucchini, 'Introduzione', Catalogo della XXIV Biennale di Venezia (Venice: Stamperia di Venezia, 1948), xii.

52 Pallucchini, 'Introduzione', xiii; also quoted in: Jachec, 'Anti-Communism at Home, Europeanism Abroad', 204.

53 Rodolfo Pallucchini to Onor. Ministero delgli Affari Esteri, 12 Nov. 1947, ASAC, Retropective e Personali 3: 3.

54 Petropoulos, The Faustian Bargain, 44-51.

55 Ibid.

56 Eberhard Hanfstaengl to Rodolfo Pallucchini, 14 Nov. 1947, ASAC, Retropective e Personali 3:3.

57 Eberhard Hanfstaengl, 'Padiglione della Germania', in Biennale di Venezia, ed., Catalogo: XXIV Esposizione biennale internazionle d'arte (Venice: C. Ferrari, 1948), 192.
} 
Munich] ${ }^{58}$ He presented German modernists as part of a European cultural heritage and as victims of the Reich. At the same time, he stressed modernism's significance for a German national identity through his emphasis on Bavarian landscapes and non-capital cities, such as Munich and Venice (rather than Berlin and Milan).

The artists to be included had made their name in a diverse collection of pre-First World War and interwar avant-garde movements. Karl Schmidt-Rottluff, Karl Hofer and Erich Heckel represented the Bridge (die Brücke); Willi Baumeister and Xavier Fuhr represented the Bauhaus; Edgar Ende the Surrealists; and Otto Dix the New Objectivity (Neue Sachlichkeit). ${ }^{59}$ Many of the works displayed in 1948 were made under the Third Reich or immediately following 1945, suggesting that the modernist tradition in Germany was so strong that even the Nazi anti-modernist policies in visual art had failed to break it. In Hanfstaengl's formulation, the avant-garde represented a true and longlasting German cultural tradition, while the National Socialists stood outside of German culture. Celebrating the avant-garde at the Biennale meant establishing an image of occupied Germany in opposition to the Nazi past and identifying with some of the Nazis' victims.

Germany's participation in the 1948 festival established the necessary preconditions for thickening ties with Western Europe and set the tone for the German Pavilion through the 1950s. Hanfstaengl's broad embrace of modernism and the avant-garde readied the ground for the more focused celebration from 1950 to 1958 of the first-generation German Expressionists. It was through these later exhibitions that he salvaged images of Germany that went beyond repudiation of the Nazis in the service of producing an assertive West German cultural image.

At the Biennale in 1950, Hanfstaengl staged a retrospective of the Blue Rider (Der Blaue Reiter, 1911-14), the Munich-based group of Russian and German artists that included Wassily Kandinsky, Franz Marc, August Macke and Gabriele Münter. Hanfstaengl presented the German Expressionist movement as a symbol of Germany's deep and historical connection to Western Europe. For Hanfstaengl, Der Blaue Reiter embodied an ideal and particularly German way of balancing European and German culture. ${ }^{60}$ He focused the exhibition on Der Blaue Reiter's paintings of the Bavarian landscape. From his perspective, the landscape paintings by Wassily Kandinsky, Paul Klee, Franz Marc and August Macke related important spiritual truths about German culture. At the same time, he proposed, they rendered the German landscape in highly abstracted forms innovated from European modernist movements. Trends in Paris, Hanfstaengl noted, influenced their new style of expression. Their openness to European trends made the national characteristics in their work more European, just as their emphasis on German landscape could serve as a German contribution to the European cultural milieu. ${ }^{61}$ In Hanfstaengl's approximation, the outcome was a marriage between a sense of German tradition, which emerged from the focus on landscape, and an unmitigated individualism, stemming from the abstracted style of the paintings. This marriage, he asserted, provided good fuel for democratic cultures. ${ }^{62}$ In other words, Hanfstaengl suggested that Germany was not only ripe for reintegration into a Western European cultural world but also that it represented a spiritual centre of the continent.

Hanfstaengl proposed a cooperative vision of German and European identity that echoed the postwar structure and mission of the Biennale. When the Nazis took over in 1933, Hanfstaengl lamented, they destroyed the balance and synergy between German and European culture by cutting Germany off from European modernism. At this point, individuality 'vanished from the horizon'. ${ }^{63}$ In its stead, the National Socialists emphasised Nazi nationalism at the expense of European integration. Hanfstaengl concluded that this type of nationalism without consideration of the broader European

\footnotetext{
58 Ibid.

59 Eberhard Hanfstaengl to Rodolfo Pallucchini, 14 Nov. 1947, ASAC, Retropective e Personali 3:3.

60 Eberhard Hanfstaengl, 'Germania', in Biennale di Venezia, ed., Catalogo: XXV Esposizione biennale internazionle d'arte (Venice: C. Ferrari, 1950), 312-13.

61 Ibid.

62 Ibid.

63 Hanfstaengl, 'Germania', 308.
} 
context was problematic. It was an aberration from the true German cultural principles, which had long emphasised healthy interchange between European and German culture. For Hanfstaengl, the return of modernists to German identity helped to redeem German culture after National Socialism. Yet, he also adapted the cultural materials of the pre-Nazi period to suit the conservative post-war landscape that understood them in terms of their German, European and democratic content.

The Austrian contributions to the Venice Biennale from 1948 through the 1950s followed a similar pattern. Like the German exhibitions, Austrian curators proposed modernist art as a way to reconnect with the pre-Nazi past. Exhibitions often featured artists who had been affiliated with the Vienna Secession at the fin-de-siècle or connected to the Klimt and Josef Hoffmann-led 'Klimt-Gruppe' that planned the 1908 Kunstschau. ${ }^{64}$ The Austrian planners used these exhibitions of modernists to sever Austrian and German cultural traditions before an international audience. From their post-war perspective, Austria and Germany represented two distinct cultural and historical traditions. As 'the first victim of National Socialism' - a status enshrined in the Moscow Declaration (1943) Austrians aimed to place post-war Austria in the good graces of the Allied forces, while also letting Austrians off the hook for their complicity in National Socialism and the Holocaust. ${ }^{65}$ Despite this attempt to disentangle German and Austrian cultures, the two states pursued parallel strategies to distinguish their national cultures from National Socialism. ${ }^{66}$ Both used modernist materials to reorient their national cultures toward Europe and to create distance with National Socialism. In other words, reclaiming a modernist past was part of a shared language of cultural reorientation without Jews in post-war Central and Western Europe.

The exhibitions fit into a broader effort to articulate a Christian and de-judaised image of Europe. Already in 1946, members of Austria's Christian Democratic Party (Österreichische Volkspartei; ÖVP) imagined international exhibitions as a cornerstone of the Second Republic's cultural policy. One 1946 ÖVP statement on cultural politics prioritised cultural diplomacy, declaring that 'Austrian art and culture is respected and in demand all over the world. It is for us a great foreign policy action and methodically planned missions are an important factor in our foreign politics'. Thankfully, 'after seven years of spiritual imprisonment by National Socialism, Austria has now opened the doors to the world of culture once again'. Austria 'can once again strive to fulfil the task that it so often calls its mission, namely, to be the bridge of intellect between the nations of the Danube area and between all nations of culture of the world'. ${ }^{67}$ Catholicism undergirded this cosmopolitan outlook. The ÖVP cultural policy explained that 'in Austria, with its old Christian tradition, culture was always tightly bound to Christianity'. The declaration continued: 'take away the Christian, the Catholic, and its culture, and it is no longer Austria'. ${ }^{68}$ In short, in the first year of the ÖVP's existence the reorientation of Austria toward Europe defined their cultural policy. Moreover, they suggested that the state's history of cosmopolitanism and Catholicism were the keys to the successful cultural rejuvenation in Austria, Europe and beyond. The argument paralleled Hanfstaengl's suggestion that West Germany represented Europe's spiritual core.

With its now blunted critical edge, Christian Democrats imagined that modernist artists shared their disdain for the materialistic-liberalism which, according to them, caused the moral vacuum that produced authoritarianism. ${ }^{69}$ Modernism - and Christianity - they proposed could help Europeans to reunite and recover the spiritual mooring lost during the fascist disaster. This revised

\footnotetext{
64 Jasper Sharp and Philipp Blom, eds., Österreich und die Biennale Venedig (Nuremberg: Verlag für Moderne Kunst, 2013).

65 See Hella Pick, Guilty Victim (London: Tauris, 2000); Oliver Rathkolb, The Paradoxical Republic (New York: Berghahn Books, 2010).

66 Frank Trommler, 'Berlin and Vienna: Reassessing Their Relationship in German Culture', German Politics \& Society, 23, 1 (2005), 8-23.

67 Kulturpolitik der ÖVP, 1946, Institut für Zeitgeschichte, Universität Wien, Nl-48 DO-327 M. 940, 13.

68 Kulturpolitik der ÖVP, 1946, Institut für Zeitgeschichte, Universität Wien, Nl-48 DO-327 M. 940, 2.

69 See Wolfram Kaiser, Christian Democracy and the Origins of the European Union (Cambridge: Cambridge University Press, 2007).
} 
modernism relied on the prior outsider quality of the works and artists, as well as the perception of modernism's victimisation at the hands of Nazi Germany's Degenerate Art Policy (which was imagined as the rule of the land across fascist Europe). These interpretations of the modernist artists and their works untethered them from the multi-ethnic contexts in which they had emerged and adapted their cosmopolitanism to suit a Christian Europe. Indeed, the prior coding that had identified modernism as cosmopolitan (and 'Jewish') was a useful foundation for Catholic cosmopolitanism after $1945 .^{70}$ At the Biennale, then, Austria, West Germany and Italy projected images of themselves that not only pushed aside the fascist epoch, but also - however flimsily - attempted to position the states as the cultural centre of Europe. It was a stunning, yet subtly executed, transformation of the function and interpretation of modernist art and artists. They were, after 1945, reinvented as representatives of a national heritage and a European identity without Jews.

\section{Modernist Artists}

Modernist artists and their representatives - often their wives and widows - became the fiercest critics of the revision of modernism during this period, directing angry missives about the manipulation of their cosmopolitan identities to the planners of the Biennale. ${ }^{71}$ Nina Kandinsky, Wassily Kandinsky's widow, rejected the attempt to celebrate her late husband within the framework of German national identity. She wrote to Pallucchini as he prepared for the 1950 Biennale, expressing her concern about the German commissioner Eberhard Hanfstaengl's plan to show Kandinsky's works in the German pavilion. For Hanfstaengl, Kandinsky represented the 'new' image of Germany as cosmopolitan, European and democratic that he hoped to promote abroad.

Nina Kandinsky, however, pointed out that her husband was not German. Wassily Kandinsky was born in Russia and obtained French citizenship in $1939 .{ }^{72}$ The time that Wassily Kandinsky had spent in Germany corresponded to his participation in avant-garde art movements. He had established Der Blaue Reiter with August Macke and Franz Marc in Munich in 1911, participating until the group disbanded in 1914. After his repatriation to Russia during the First World War, Kandinsky returned to Germany to collaborate with the Bauhaus. Thus, his engagement with Germany was largely professional. If anything, Nina Kandinsky argued, his operative national identity at the Biennale should reflect the more serious national commitments of Russian birth and French citizenship. ${ }^{73}$ Her comments about his citizenship reflected more fundamental concerns about the translation of the cosmopolitan artist who lived across many European cities to an exhibition that categorised artists along national lines. In other words, Kandinsky's letter revealed the revisionist work that bureaucrats and politicians had done to translate modernist artists to the post-fascist period.

A similar pattern emerged with the exhibition of Oskar Kokoschka in 1948. Kokoschka had come of age at the turn of the century, participating in the Vienna Secession and the Expressionist group that broke away from the Secessionists in 1907. One of the most celebrated living Austrian-born artists, Kokoschka had a complicated relationship with the Second Republic. He had been a radical representative of artistic innovation in turn-of-the-century Vienna but had spent the majority of his professional life outside of Austria. He was one of only two Austrian artists included in the Austrian version of the Degenerate Art Exhibition (1938) - the other was William Thöny. ${ }^{74}$ In the Austrian version of the exhibition, National Socialists coded Kokoschka and his work as 'Jewish' (though he was not Jewish). Kokoschka fled Austria, settling in London.

\footnotetext{
70 Sam Moyn makes a parallel argument about the Christian Democratic revision of human rights. Moyn, Christian Human Rights (Philadelphia: University of Pennsylvania Press, 2015).

71 In so doing, they reflect a long-standing history of modernists rejecting the appropriation of their work by state elites. They did so, however, in a moment when the coordinates used to interpret modernism underwent a radical transformation. See Winkler, Museum und Avantgarde, 2002.

72 Nina Kandinsky to Roldofo Pallucchini, Nov. 1949, ASAC, Personali XXV 024: 7.

73 Ibid.

74 Ploil, 'The "Entartete Kunst” Exhibitions in Austria'.
} 
In response to the possibility that Kokoschka's work might be brought into the Austrian pavilion at the Biennale, Olda Kokoschka, the artist's wife, noted the artist's tenuous connection to Austria:

We have talked here with the Representative of the Austrian Government, who seems to assume, that Kokoschka is exhibiting in Venice as an Austrian in the frame of the Austrian Section. As your original suggestion was nothing of the kind, OK (Oskar Kokoschka) most urgently requests you to see to it, that this exhibition is a separate one, a one-man exhibition independent of national or state-groups. Any other way would put him into a queer position, if only for the reason that, born Austrian, he has had a Czechoslovak passport from 1935 to 1947, and for something over a year is a naturalized British subject. Circumstances forced him to do this and the Austrians can really claim him only on the strength of his birth, because all his life they have made it again and again impossible for him to live and work in Vienna. He is having exhibitions always on the strength of his name and reputation as an individual and assumes that his participation in the Biennale was from the beginning meant thus. ${ }^{75}$

Her husband, she explained, refused to be used as a sort of 'poster child' (ein Aushängeschild). ${ }^{76}$ Kokoschka favoured an interpretation of his art and biography that defied his incorporation into a national aesthetic programme.

After 1945, Kokoschka and his work retained aspects of their prior Jewish coding. This contributed to the paradoxical relationship with the Second Republic that came to a head in this exchange regarding preparations for the 1948 Biennale. While the Austrian commissioners of the Biennale hoped to claim Kokoschka as their own in the international exhibition, he was often excluded from early postwar exhibitions at home and abroad. Attempts to return the artist to Salzburg faltered in the early post-war period due to the reluctance of post-war bureaucrats to provide housing for the artist. Even the symbolic return of the artist failed. The first post-war administrator of cultural affairs in Vienna, Viktor Matejka, tried to convince the city council to grant Kokoschka honorary citizenship in 1946 to mark the artist's sixtieth birthday. Council members rejected his proposal, claiming that Kokoschka did not fit the requirements for such an honour. Some skirted the issue and declared that he 'ought to be seventy-years-old first'. More revealingly, despite Kokoschka's Austrian birth and the fact that other non-Austrians (for example Richard Strauss) had received the award previously, council members rejected the proposal on the grounds of Kokoschka's 'foreign birth'. ${ }^{77}$ In 1946, Kokoschka's exclusion had reaffirmed the boundaries of the Austrian nation and cultural world as exclusive of émigrés, 'Jews' and 'degenerate' art. Meanwhile, the desire to claim the artist for Austria at the Biennale in 1948 and the trajectory of the artist's career suggest an appreciation for the artist's European and cosmopolitan outlook coexisted with, and eventually replaced, the disdain for the artist's so-called 'foreignness'. Kokoschka was incorporated into the Austrian cultural canon as a representative of a specific brand of Austrian identity, oriented toward Europe, but still decidedly Austrian.

The antisemitic and philosemitic code that served as the subtext of Kokoschka's inclusion in the Austrian cultural canon was still apparent in his correspondence with the art dealer Friedrich Welz in 1966. In a letter to Kokoschka that Welz published as the foreword to his 1966 exhibition of the artist, he revealed that Kokoschka's 'School of Seeing' - a summer school that the artist ran in Salzburg for young artists from 1953 to 1963 - had always been 'seen here only as a tourist attraction'. Still, Welz accused Kokoschka of denying 'his Austrian soul' by remaining abroad. Welz noted his bitterness that the authorities had failed to support the artist's initial post-war desire to take up residence in Salzburg after 1945. 'What would it mean for Salzburg, if you were its citizen today', Welz

\footnotetext{
75 Olda Kokoschka to Pallucchini, London, 28 Feb. 1948, ASAC, 5: FC.

76 Ibid.

77 Viktor Matejka, 'Der Fall Kokoschka', 29 Oct. 1960, Wienbibliothek im Rathaus-Handschriftensammlung, Nachlass Viktor Matejka, ZPH 830/17.
} 
ruminated. 'The city . . c could today be a centre of European visual arts if it had you, such a great master and teacher in its midst'. ${ }^{78}$ From this perspective, Welz suggested that Austrians were the true victims of the twentieth century, having lost their connection to culture. Welz suggested that Kokoschka and his art were at once perceived as foreign and made for tourists, and also as representative of an authentic Austria that might help to reconnect the state with its past as a Kulturnation. Kokoschka embodied a figure who could restore a cultural connection to the pre-Nazi period but also carried the burden of responsibility for cultural dullness because of his absence. In this way, in his engagement with the non-Jewish Kokoschka, Welz invoked the antisemitic image of the 'Jew' as responsible for inauthentic culture by 'his' presence and for the lack of domestic creativity by 'his' absence.

\section{Missing Jews}

The stifling post-war landscape and the national structure of the Biennale left little room for living Jewish artists, dealers and curators to participate in the festival. The Viennese Jewish art dealer Otto Kallir, for example, commented on a radical reversal in Austria's post-war aesthetic policy. Kallir, who had championed modernist artists during the interwar period and worked to popularise them abroad in exile, noted bitterly that Richard Gerstl's works were 'even last year given the honor of representing Austria at the Venice Biennale [whereas in] the 1920s and 1930s, he received no help of any kind in Vienna'. ${ }^{79}$ According to Kallir, the exhibitions of modern art at his interwar Viennese gallery attracted the praise of art critics from across Europe, but never received support from the municipal or state authorities as was the case in the postwar period. After 1945, Austrian officials excluded Kallir from the cultural scene by refusing to collaborate with him on international exhibitions of the modernist artists he had been instrumental in promoting. ${ }^{80}$

The London-based art critic J.P. Hodin was also sensitive to the issue of Jewish exclusion from the Biennale and the post-war contemporary art scene. Born in Prague in 1905 to a German-speaking Jewish family, Hodin fled from Germany (where he was studying at the Academy of Art in Berlin) in 1933. After seeking refuge in Paris and Stockholm, he made a more permanent home in London in 1944. There, he became an active participant in the British art world and published a number of important works on modernism. ${ }^{81}$ In 1952, Hodin wrote to Pallucchini about the national structure of the Biennale. After many conversations with artists, he explained that:

there was one problem which struck me as of possible interest to you ... The national standpoint has indeed a restricting effect on the selection of artists for the national pavilions of the Biennale. Since the unfortunate political developments of the last decades a great number of very talented artists enjoy the hospitality of the countries of the West. They rarely have a chance of exhibiting their works in an international forum. Because they do not represent the 'national' cultural values of the exhibiting nations. They represent the freedom of expression which had been assured to them, a valuable European heritage. ${ }^{82}$

Hodin was highlighting the paradox of the Biennale as a reflection of the contemporary art scene in Europe: refugee artists, according to Hodin, provided the best example of the 'European heritage' of the 'freedom of expression' celebrated by the architects of the Biennale and the revision of modernism in the West. Yet as stateless artists they were defined outside of the boundaries of the national pavilions. Hodin, like Léo Maillet, suggested that Pallucchini could resolve the problem with the

\footnotetext{
78 Friedrich Welz, Kokoschka zum 80. Geburtstag (Salzburg: Galerie Welz, 1966).

79 Otto Kallir to Eleonore Thun, 28 Nov. 1957, Archive, Kallir Research Institute, NY. Gerstl, who died in 1908, had a Jewish father but was presented in 1956 along the lines of Koskochka - as a European and cosmopolitan representative of Austria.

80 Ibid.

81 For example: J.P. Hodin, Modern Art and the Modern Mind (Cleveland: Case Western Reserve University, 1972).

82 J.P. Hodin to Rodolfo Pallucchini, 16 Nov. 1952, ASAC, Box 043, XXVI Biennale 1952. Atti II: 1950-3.
} 
construction of 'a pavilion dedicated to the artists without a country ... with the emphasis on their freedom of creation, it would be a feature widely appreciated not only for its moral value but also for the sake of the completeness with which the contemporary scene might be presented' ${ }^{83}$ Hodin imagined an alternative to the Biennale's interpretation of European heritage on a national basis. $\mathrm{He}$ implied that refugee experiences should also be considered foundational to European history and culture in the moment of cultural reconstruction and Cold War contest. His criticisms fell on deaf ears. The Biennale planners did not act on the suggestion to establish a pavilion for stateless artists. Instead, they perpetuated their version of catholic cosmopolitanism tethered to a national cultural revival that left only narrow spaces for Jewish cultural figures.

\section{Conclusion}

This article suggests that we might understand the post-war period, then, as another chapter in the history of Jewish and non-Jewish relations, this time shaped by the unbridgeable void left by the Holocaust. Post-Nazi curators and bureaucrats retained the perspective - at least implicitly - that there was a productive relationship between modernism and cultural dynamism. They believed that bringing modernism into a national framework would revive cultural life in the wake of its destruction during the fascist period. They wanted to benefit from the enforced cosmopolitanism of non-Jewish artists like Oskar Kokoschka. Yet, they did not wish to reintegrate the living protagonists of modernist movements whose biographies challenged the principles of the post-war reinterpretation of modernism. Jews and the artists or materials coded 'Jewish' were at once excluded from participation in postwar culture in key moments, blamed for a perceived cultural dullness and imagined as redemptive forces that would help bring post-fascist states back to their pre-Nazi past. This process reveals one important consequence of genocide: the desire to absorb and redefine the culture produced by or associated (through stereotype) with the victims in their absence. ${ }^{84}$

The retrospective focus on modernism at the Biennale concluded by the early 1960s. Other trends took over and an increasingly critical perspective challenged the celebration of national identities at the Biennale, as well as the version of European identity that the exhibition represented. The tensions of exclusion and symbolic representation, however, still inform the debates about European identity that unfurl across the Giardini.

Visitors to the 58th Venice Biennale of Art in 2019, for example, encountered the rusted remains of a fishing boat parked in the Arsenale, a former dockyard now used as an exhibition space for the important international festival. Barca Nostra (Our Ship) is the provocative installation by the Swiss-Icelandic artist Christoph Büchel. Before finding its way to the Giardini the ship became the site of one of the deadliest disasters of the ongoing refugee crisis involving migrants crossing the Mediterranean for European shores. Meant to hold a crew of fifteen, the overcrowded boat, manned by an inexperienced captain, capsized off the coast of Libya on 18 April 2015 after colliding with a Portuguese freighter that had come to its aid. The accident killed an estimated 800 refugees with only twenty-eight survivors. ${ }^{85}$ In the aftermath of the disaster, the Italian navy recovered the ship to identify the victims and provide evidence for the court case of the captain, who was found guilty of manslaughter. With Barca Nostra, Büchel transforms the ship from legal evidence to 'bene culturale, a significant symbol of our "interesting times", collective complicity, and memory'. ${ }^{86}$ The artist hoped

\footnotetext{
83 Ibid.

84 In other contexts: Robert Geraci, 'Genocidal Impulses and Fantasies in Imperial Russia', in A. Dirk Moses, ed., Empire, Colony, Genocide: Conquest, Occupation, and Subaltern Resistance in World History (Oxford: Berghahn Books), 343-71; Eve Tuck and Rubén A. Gaztambide-Fernández, 'Curriculum, Replacement, and Settler Futurity', Journal of Curriculum Theorizing, 29, 1 (2013), 72-89; Patrick Wolfe, 'Settler Colonialism and the Elimination of the Native', The Journal of Genocide Research, 8, 4 (2006), 387-409.

85 Julian Miglierini, 'Migrant Tragedy: Anatomy of a Shipwreck', BBC News, 24 May 2016, available at https://www.bbc.com/ news/world-europe-36278529 (last visited 23 July 2019).

86 Christoph Büchel, Barca Nostra Press Release, 2019. Here, Büchel is referencing the theme of the Biennale set by curator Ralph Rugoff, 'May You Live in Interesting Times'.
} 
the installation would encourage visitors to consider 'our mutual responsibility for the collective policies and politics that create such wrecks' ${ }^{87}$ Büchel's installation, like Hodin and Maillet's lamentations, suggests that the stories of refugees, and the tragedies that befall them due to stringent immigration laws and nativist politics, are part of a shared European - in fact, global - history.

Barca Nostra excited the intense controversy sought by the artist. ${ }^{88}$ Within the art world, some critics noted that the project created yet another photo opportunity for the mass of tourists passing through the Biennale each summer. Curator Vincent Honoré, for example, explained that the potential for selfies made him 'nauseous'. ${ }^{89}$ Meanwhile, Matteo Salvini, the leader of Italy's Eurosceptic and nativist far-right Northern League, called the installation 'propaganda' and suggested its transfer to Büchel's homeland in Switzerland. ${ }^{90}$ Their opposing political perspectives notwithstanding, both overlooked the fundamental challenge the work poses to the Europeanist mission that has cemented the Biennale's significance during the second half of the twentieth century. While Barca Nostra responds directly to the ongoing refugee crisis, it is also a counter-monument that lays bare a tension at the heart of the Biennale as a site of cultural diplomacy: the contradiction between the cosmopolitan fantasies projected by participating nations onto the festival and the reality of exclusion in contemporary Europe. ${ }^{91}$ This contradiction, then, continues to evolve and shape the agenda at the Biennale as the exhibition confronts the paradoxes of belonging in Europe.

Acknowledgements. This article has benefited from the insightful comments of many friends and colleagues through several rounds of revision. I am grateful to Omer Bartov, Mary Gluck, Maud Mandel, and the Modern Europe Working Group at Brown University, who read an early draft of this paper. I am also grateful for the careful readings of Dirk Moses, Nina Valbousquet and the anonymous referees.

87 Quoted in Elisabetta Povoledo, 'Wreck of Migrant Ship that Killed Hundreds Will Be Displayed at Venice Biennale', New York Times, 6 May 2019, available at https://www.nytimes.com/2019/05/06/arts/design/migrant-boat-venice-biennale-christian-buchel.html (last visited 23 July 2019).

88 A number of articles in the art and more general press have reflected on the controversy. For example: Christina Ruiz, 'Fierce Debate over Christoph Büchel's Venice Biennale Display of a Boat that Sank with Hundreds Locked in Hull', The Art Newspaper, 14 May 2019, available at https://www.theartnewspaper.com/news/christoph-buechel (last visited 23 July 2019); Lorenzo Tondo, 'I Have Seen the Tragedy of Mediterranean Migrants. This “Art” Makes Me Feel Uneasy', The Guardian, 12 May 2019, available at https://www.theguardian.com/world/2019/may/12/venice-biennale-migrant-tragedy-art-makes-me-uneasy (last visited 23 July 2019).

89 Vincent Honoré, Instagram Post, 13 May 2019, available at https://www.instagram.com/p/BxZJU7-FVGD/ (last visited 23 July 2019).

90 Büchel, in fact, has a history of bringing such challenges to the Biennale, demonstrated by his contribution to Iceland's pavilion at the Biennale in 2015, The Mosque: The First Mosque in the Historic City of Venice. The exhibition transformed a tenth-century Italian church into a mosque. After complaints by the far right, Venetian authorities closed the exhibition, citing a permit violation. See L. Bialasiewicz, 'That which is not a Mosque': Disturbing Place at the 2015 Venice Biennale', City, 21, 3-4 (2017), 367-87.

91 See James Young, 'The Counter-Monument: Memory Against Itself in Germany Today', Critical Inquiry, 18, 2 (1992): 267-96; Young, The Texture of Memory (New Haven: Yale University Press, 1993).

Cite this article: Tanzer F (2022). European Fantasies: Modernism and Jewish Absence at the Venice Biennale of Art, 19481956. Contemporary European History 31, 243-258. https://doi.org/10.1017/S0960777321000138 